\title{
Principles of Humanitarian Law in the War Biography of Imam Ali (Peace be upon Him) the Equestrian Principle and Proportionality as a Model
}

\author{
Amer Abdul Hussein Abbas ${ }^{1}$, Thamer Mohamed ${ }^{1}$ \\ ${ }^{1}$ Lecturer, Republic of Iraq, University of Kufa, Faculty of Law
}

\begin{abstract}
The biography of Imam Ali included the most human principles and rules, and his war biography was a mixture of justice, fairness and mercy. This brief study reached several results, which we summarize as follows: The Imam hated war and pushed it as long as he found a way to do that. The basic principle for him is the state of peace, and war is an exceptional and urgent case, and all his wars were self-defence, a response to aggression and the payment of sedition and corruption. The Imam prevailed in his battles against humanism over the necessities and requirements of war, so love, peace, compassion and mercy were the basis of his personality, and his perseverance was forgiveness and tolerance, even if that led to the loss of victory, as happened in the incident of the law of water in the battle of ((Safin)). The principle of chivalry was evident in its most beautiful form in the personality of the Imam, with the qualities of honesty, courage and arrogance he carried.
\end{abstract}

Keywords: Humanitarian law, biography of Imam Ali, Proportionality as a Model.

\section{Introduction}

The personality of Imam Ali (peace be upon him) is distinguished by its many dimensions and its intellectual, scientific, spiritual and literary aspects ... and each dimension has its great human value and value, and among those bright dimensions is its humanity in war and his unique horsemanship ${ }^{1}$ with the values of nobility, magnanimity, fairness and mercy of enemies. His military career included many humanitarian principles, what he calls - today - international humanitarian law. The importance of the research stems from the fact that it deals with a modern vital topic that has little experience, especially since the issues of humanitarian law are among the studies developed in our universities. Research reasons and objectives:

1. The research aims to show the greatness of Islam and its human and moral civilization, by reviewing some of the positions of Imam Ali (PBUH) - in word and deed - in war and what is related to its affairs, as his war history represents in that the true approach of Islam.

2. On the occasion of the passage of one thousand four hundred Hijri years since the martyrdom of the Imam (PBUH), the University of Kufa decided to consider this year - $1440 \mathrm{AH}$ - as its own and direct its professors to show some aspects of this great personality.

3. Many subjective reasons, including familiarity with and depth of most issues of humanitarian law and the diversification of our legal research.

The research problem: It is represented in knowing the extent to which Imam Ali's war biography includes the most important principles of humanitarian law and their application before their appearance in Western civilization.

\section{Methodology}

We followed the descriptive historical method, the legal analysis method, as well as the comparative approach.

\section{Search Plan:}

For the sake of brevity, we will address the topic in two main points: 
First: Humanism in In the military biography of Imam Ali.

Second: The principles of chivalry and proportionality.

The conclusion comes with the summary, results and recommendations it contained, and then the approved sources.

\section{First: the humanism in the military biography of Imam Ali}

The military biography of Imam Ali. consists of two stages:

1. The First: During the era of the Messenger (PBUH) -1-11 AH- in which the Imam was a military commander in what is used - today - in military terms ((Chief of Staff of War)), and at this stage, he participated in all the major wars of Islam led by the Messenger (p.) Himself, as the Messenger sent him during this period as commander of several companies - Khaybar - Fadak - Yemen, and others.

2. The Second: The days of his caliphate $35-40 \mathrm{AH}$ and in it, he was the political leader of the nation and the supreme commander-in-chief of the armies of the Islamic state, and in which he led the major internal wars himself - Al-Jamal-Siffin-Al-Nahrawan.

In both phases, his military practices manifested the humanism that is the model for noble warriors, bypassing the requirements and necessities of war. The war did not have a means of extending influence and control, nor did it aim to heal and retaliate or exterminate the opponent, and he only fought it in defence of freedom of belief and the security of the state and society.

The evidence for this in his war biography are many, including that he did not invite anyone to fight him, and if he was invited he answered, thus recommending his son Al-Hassan: ((Do not call for a duel, and if you are called, then he will answer, for the caller is absent and the perpetrator is killed) $)^{1}$. Bin Wad in the battle of the Trench is what confirms this. Before confronting him, Islam offered him or return and peace ${ }^{2}$, and if he met the two armies he would not authorize the fighting until he offered peace and return to the enemies and frightened them with the consequences of the war, and he invoked his words: ((Oh God, inject our blood and their blood and reform the self) Between us and them, and save them from their misguidance so that the truth is known from his ignorance, and he feeds on the treachery and treachery of his accusers) $)^{3}$.

This is what happened in the Battle of the Camel. After the leaders of the other side responded to his envoys and did not heed his advice, he remained until the last moment, appealing to them and inviting them to peace, and one of his companions sent them with the Qur'an in hand to offer them his arbitration and they killed him, and then they attacked his army, so he said: $((\mathrm{Oh}$ God, bear witness ... $)){ }^{4} \mathrm{He}$ had no choice but to defend himself and repel aggression.

Thus he did with Muawiyah and the people of Levant before the battle of ((Safin)), as they were guided by the month of Muharram from the year $-37 \mathrm{AH}$ - so that they might respond to the call of reason and humanity. God Almighty, by calling you to him, you did not refrain from tyranny, and you did not answer to the truth, and I rejected you the same because God does not love the traitors)) ${ }^{5}$, and he used to recommend his soldiers before meeting the enemy in two ranks by his famous saying: ((Do not fight them until they start you, for you Praise be to God for proof, and he left you until they start another argument for you on them)). ${ }^{6}$

And this is how his position was with the internal opposition - the outside - where he dealt with them with unprecedented humanity, for after they broke with his rule and opposing him, he did not imprison them or restrict them, nor did he exclude them from participating in political life, and they would attend the mosque with him, discuss it and pray alone, and he protested them several times and obeyed He had many of them, and decided to deal with them by saying: ((You have three times with us, we do not prevent you from praying in this mosque, and we do not prevent you from your share in this category - what your hands were with ours - and we do not fight you until you fight us)) ${ }^{7}$ And when they announce the disobedience and rebel Corruption on the ground and they killed the Muslims, who wrote them and warned them against the consequences of war and preached them, and when the battle took place on them he raised a flag of safety for them, as he allowed those who wanted to leave the war to leave, and healed their wounded $^{8}$

Upon studying his war behaviour, we see that his war was not an unrestrained war with no boundaries, but rather disciplined and moderate, in which he refrained from using harsh or hideous method and means under 
any circumstance or name - such as the necessities of war or reciprocity, and his war behaviours stemmed from an innate and moral human capacity. Sublime, his actions and war stances were validation of what ((Grosius)) looked to him after ten centuries defending the controls of moderation in war ${ }^{9}$.

Among these behaviours was the incident of the Sharia of water in the Battle of Siffin, where Muawiya's army took control of it first, and they decided to put the Imam and his army to death by thirst. And his leaders were to prevent Muawiya's army from it and exterminate them thirst, or they surrendered to a reciprocal treatment, so the imam refused that and left between them and the water and said to his commanders: ((Indeed, God has given you victory over them by their injustice and their intent ... and all water is in it)) ${ }^{10}$

This is the core and essence of humanitarian law and its goal that it seeks to achieve.

Second: The principle of chivalry and proportionality of Imam Ali: Humanitarian law is based on a set of basic principles whose origins are traced back to humanitarian, religious and ethical sources. They existed before the emergence of the law and governed after its codification. The conventions may explicitly mention them in the preamble or the context with the expression ((laws of humanity)) or ((the prevailing custom)) or ((What is dictated by the general conscience)), and it applies to all times and places ${ }^{11}$, and we will deal with it in this point two basic principles, as follows:

1. The Equestrian Principle: It is an ancient principle known to most nations, including the Arabs, and emerged in the Middle Ages among the Romans and Franks after they converted to Christianity, and the principle is the qualities of heroism and nobility in a knight or a fighter, which necessitate refraining from treachery, treachery, deception, or the use of excessive force and brutality or prohibited weapons, and all that It would avert honour, and the principle also requires not to finish off a wounded, unarmed or prisoner, or attack civilians and loot their property, and among the equestrian rules is reciprocity, and unfortunately, previously Christian countries did not apply them to non-Christians, especially in their Crusades against Muslims ${ }^{12}$ which were committed It contained the most heinous human crimes until it came to decorating some churches with the bones of Muslims ${ }^{13}$.
The principle contributed to alleviating the pain of war and sparing non-combatants from its woes.

It is not an exaggeration to say: The most perfect validation of the principle is the person of the Imam, because of the qualities and morals of the knights he possessed, and in that he says - Carlyle -: ((As for that boy Ali you cannot help but love him, God has installed nobility in his character since modernity, In its shade, generosity was manifested throughout his life, and then it was imprinted on work, impassion and frankness of strength, and the mystery of chivalry and the boldness of the Layth came to him, and all of this was in the tenderness of the heart, sincerity of faith, and effective generosity worthy of Christian chivalry). ${ }^{14}$

It is not mentioned in its history that he betrayed a covenant or betrayed anyone, who said: ((Loyalty is the twin of sincerity, and I do not know a better paradise than it ... We have become in a time when most of his people have taken treachery and attributed them to the people of ignorance in it to good resourcefulness ..., he may see the change. The heart is the face of the trick, and without it is an objection to the command of God and forbids it, so it allows it to see the eye after being able to it, and it takes its opportunity for the one who does not need religion)). ${ }^{15}$

And he confirmed this in his covenant to the owner of Ashtar - when the ruler of Egypt - saying: ((If you made a knot between you and your enemy or clothe him from you, then make your pledge to honour your commitment and make yourself a paradise as you were given ... so do not be betrayed by your responsibility and do not betray your pledge ...)). ${ }^{16}$

He also did not mention in his fights and wars despite their many - that he killed someone from behind or killed a wounded person. Rather, in his wars, he used to repeat his commandment to his commanders and companions that: ((... do not kill a mastermind, and do not prepare against a wounded ...)) ${ }^{17}$ Historians have mentioned His duel in ((Battle of Uhud)) for one of the leaders of the great polytheists - Talha bin Othman where he called for the duel, so the imam went out to him, cut his leg and left it. The imam was told:

((Could I be ready for him, so he said: God and the Womb have appealed to me, and I have stopped him) $)^{18}$, and this is the core of the equestrian principle.

2. The principle of proportionality: It is an ancient principle that emerged under the principle of 
chivalry and was established after the spread of Christianity, and it is a compromise principle that seeks to establish a balance between two opposing interests, the first being the war imperatives, which allows the use of violent method and means of combat to defeat the enemy and achieve victory even if that leads to excruciating pain. And heavy losses among combatants, and even civilians, who are covered by special protection, while the other interest is represented by humanitarian requirements and considerations, which prohibit the use of unfamiliar or brutal method and means of combat and prevent excessive injuries, and call for civilians and those covered by special protection, such as the wounded and sick, to be spared the scourge and pain of war.

\section{Conclusion}

The biography of Imam Ali included the most human principles and rules, and his war biography was a mixture of justice, fairness and mercy. This brief study reached several results, which we summarize as follows: The Imam hated war and pushed it as long as he found a way to do that. The basic principle for him is the state of peace, and war is an exceptional and urgent case, and all his wars were self-defence, a response to aggression and the payment of sedition and corruption. The Imam prevailed in his battles against humanism over the necessities and requirements of war, so love, peace, compassion and mercy were the basis of his personality, and his perseverance was forgiveness and tolerance, even if that led to the loss of victory, as happened in the incident of the law of water in the battle of ((Safin)). The principle of chivalry was evident in its most beautiful form in the personality of the Imam, with the qualities of honesty, courage and arrogance he carried. The Imam applied the principle of proportionality in his wars, so he did not use unfamiliar and despicable method of brutal weapons, such as killing the enemy at night or using poisonous weapons, and he did not go too far in killing or eradicating enemies, and he was content with achieving victory on the battlefield, and this is the essence of proportionality. The significance of what was stated in the proclamation of Saint Peter Burg - 1168.

\footnotetext{
Financial Disclosure: There is no financial disclosure.
}

Conflict of Interest: None to declare.

Ethical Clearance: All experimental protocols were approved under the University of Kufaand all experiments were carried out in accordance with approved guidelines.

\section{References}

1. Bin Jaafar A. commented on: Khalil al-Mansur, Shariat printed, Qom, without mentioning the number and year of printing.2000.

2. Al-Zayat AH. History of Arabic Literature, Dar Nahdet Misr for Printing and Publishing, Cairo, 26th Edition, without mentioning the year of printing.

3. Ahmed Abis Nehme Al-Fatlawi, International Humanitarian Law, Zain Human Rights Publications, Beirut, 1st Edition, 2019.

4. Al-Tamimi A. deceived the ruling and deceived the word, publications of the Al-Alamy Foundation for Publications, Beirut, 1st Edition, 1987.

5. Al-Tabarsi HA. Mustadrak Al-Waseel and Creator of Issues, Aal Al-Bayt Foundation for the Revival of Heritage, Beirut, 2nd Edition, 1988.

6. Al-Madani I. Explanation of Nahj al-Balaghah, edited by Muhammad Abu al-Fadl Ibrahim, AlHakim Library - Damascus, Arab Book House Baghdad, 2005.

7. Al-Masoudi A. Promoter of Gold and Minerals AlJawhar, edited by Mohi El-Din Abdel-Hamid, Dar Al-Anwar, Beirut, 1st Edition, 2009.

8. MakkiO. International Humanitarian Law in Contemporary Armed Conflicts, a group of researchers, prepared by Omar Makki, from the publications of the International Committee of the Red Cross -ICRC-, without mentioning the year and edition number.

9. Al-Tabari M. History of Nations and Kings known as the History of al-Tabari, investigation and comment: Abd A. Ali Muhanna, Al-Alami Company for Publications, Beirut, 2nd Edition, 2012.

10. Al-Hassan M. known as Al-Hur Al-Amili, the Shiites' means of attaining Sharia issues, corrected and followed by Muhammad Al-Sarazi, House of Revival of Arab Heritage, Beirut, without mentioning the number and year of printing.

11. Al-Majzoub M. International Humanitarian Law, Al-Halabi Human Rights Publications, Beirut, 1st Edition, 2009. 
12. Al-Zamali A. Articles on International Humanitarian Law and Islam, a group of researchers, compiled, collated and revised by Amer Al-Zamali, International Committee of the Red Cross-ICRC Publications, Cairo, 2007.

13. Al-Anbaki N. International Humanitarian Law, Wael Publishing House, Amman, 1st Edition, 2010.
14. Al-Balaghah N. which is a collection of speeches of the Commander of the Faithful Ali (PBUH), his books, letters, and his wisdom compiled by Al-Sharif Al-Radhi d.406 AH, explained by Muhammad Abdo, whose sources are: Faten Muhammad Khalil al-Laboun, Arab History Foundation, 1st Edition, Beirut, without mentioning the year of printing. 2000. 